\title{
PERUMUSAN STRATEGI PENGEMBANGAN INDUSTRI KECIL MENENGAH TOPENG MALANGAN
}

\author{
SUNDAY NOYA*, KHOIRUL HIDAYAT, DAN MELANY \\ Program Studi Teknik Industri, Universitas Ma Chung \\ Jalan Villa Puncak Tidar N-01, Malang 65151 \\ Surel: sunday.alexander@machung.ac.id
}

\begin{abstract}
ABSTRAK
Topeng Malangan adalah salah satu produk budaya yang potensial dikembangkan untuk melestarikan budaya serta mendatangkan pendapatan bagi masyarakat pelaku usaha di Malang. Penelitian ini bertujuan mengidentifikasi faktor-faktor internal maupun eksternal yang memengaruhi keberadaan IKM Topeng Malangan dan merumuskan strategi pengembangannya. Identifikasi permasalahan dan faktor-faktor tersebut dilakukan dalam Focus Group Discussion (FGD) yang melibatkan pelaku usaha, pemerhati budaya, akademisi, pemerintah daerah dan peneliti. Hasil FGD kemudian dianalisis dan dikembangkan dengan matriks SWOT sehingga menghasilkan rumusan strategi pengembangan IKM Topeng Malangan. Untuk mempertajam rumusan strategi ini agar lebih efektif dalam implementasinya, maka dilakukan pula analisis menggunakan matriks IFAS dan EFAS. Hasilnya adalah rumusan akhir strategi pengembangan IKM Topeng Malangan yang lebih berkonsentrasi pada strategi SO (Strength-Opportunities) yakni penggunaan kekuatan yang dimiliki IKM Topeng Malangan untuk memanfaatkan peluang secara maksimal.
\end{abstract}

Kata kunci: strategi pengembangan, IKM, topeng malangan, SWOT

\begin{abstract}
Topeng Malangan is one of potential cultural products developed to preserve culture and bring revenue for stakeholder in Malang. This study aims to identify internal and external factors affecting the existence of small medium enterprise (SME) Topeng Malangan and formulate its development strategy. The identification of problem and factors is done by focus group discussions (FGD) involving businessmen, cultural observer, academician, regional government and researchers. The results of FGD is then analyzed and developed by using SWOT matrix in order to determine formula of SME development strategies. To sharpen the strategy more effective in implementation, the analysis using IFAS and EFAS matrix is conducted. The result is final formula for SME Topeng Malangan development strategy that is more focused on strategy SO (Strength - Opportunities); which is the utilization of strength organization of SME Topeng Malangan for taking advantage of opportunities.
\end{abstract}

Key words: development strategy, SME, topeng malangan, SWOT

\section{PENDAHULUAN}

Malang adalah nama sebuah wilayah di Jawa Timur yang terkenal dengan keindahan alamnya. Di balik keindahan alam dan keasrian tersebut, ternyata Malang memiliki produk budaya yang bernilai sangat tinggi yaitu Topeng Malangan. Berdasarkan beberapa catatan sejarah, disebutkan bahwa Topeng Malangan adalah sebuah kesenian kuno yang usianya lebih tua dari keberadaan Malang itu sendiri. Kini, Topeng Malangan dapat disebut sebagai ikon Malang. Hal ini menunjukkan bahwa Topeng Malangan adalah salah satu produk budaya yang potensial untuk dikembangkan khususnya untuk melestarikan budaya serta mendatangkan pendapatan bagi masyarakat pelaku usaha. Topeng Malangan harus dilestarikan sebagai salah satu warisan budaya yang bernilai tinggi

* Penulis korespondensi 
sekaligus harus dapat dikembangkan menjadi industri potensial yang memberikan nilai ekonomi. Saat ini ada beberapa sanggar yang membuat langsung Topeng Malangan serta mementaskannya. Sekitar lima hingga tujuh sanggar Topeng Malangan yang masih eksis keberadaannya untuk terus memproduksi Topeng Malangan berlokasi di daerah di Kedungmonggo (Sanggar Asmoro Bangun), Jabung (Wayang Topeng Wira Bhakti dan Grup Wayang Topeng Dusun Precet), Sumberpucung (Wayang Topeng Jambuwer Kromengan, Wayang topeng Desa Jatiguwi dan Wayang topeng Desa Senggreng), Jambuwer (Sanggar galuh Candra Kirana), di Glagahdowo (Sanggar Sri Margo utomo) serta beberapa sanggar di daerah Tumpang (Indriasari, 2013).

Penelitian yang mengangkat eksistensi dan strategi pertahanan Tari dan Topeng Malangan di Malang Raya menunjukkan bahwa keberadaan Topeng Malangan masih belum dikenal bahkan di kalangan orang Malang sekalipun. Minimnya informasi mengenai Topeng Malangan serta publikasi yang sangat jarang menjadi alasan utama kurang dikenalnya budaya dan industri Topeng Malangan (Melany, 2012). Syahza (2003) meneliti tentang program ekonomi masyarakat yang berbasis kerakyatan sedang gencar dikembangkan di Kabupaten Indragiri Hulu, karena dapat meningkatkan dan mengembangkan dunia usaha terutama usaha kecil dan menengah (UKM). Dalam pengembangan UKM ini masih ditemukan permasalahan, antara lain: lemahnya struktur permodalan dan akses terhadap sumber permodalan; ketersediaan bahan baku dan kontinuitasnya; terbatasnya kemampuan dalam penguasaan teknologi; lemahnya organisasi dan manajemen usaha; dan kurangnya kuantitas dan kualitas sumber daya manusia. Salah satu alternatif pemecahannya adalah memberdayakan lembaga ekonomi pedesaan yaitu koperasi. Selain itu, beberapa penelitian telah merumuskan strategi pengembangan UKM. Dua diantaranya adalah, penelitian Rahmana dkk. (2012) yang merumuskan pengembangan UKM sektor industri pengolahan dan penelitian Herdhiansyah dkk.
(2012) yang merumuskan strategi pengembangan agroindustri. Kedua penelitian ini menggunakan metode SWOT untuk merumuskan strategi dan menentukan prioritas strategi yang akan diterapkan pada kedua jenis industri.

Pelestarian Topeng Malangan membutuhkan beberapa usaha serta strategi yang matang agar tercipta harmonisasi kepentingan baik dari pihak pemerintah, swasta serta pihak-pihak terkait lainnya. Pelestarian Topeng Malangan ini akan memberikan dampak positif bagi citra maupun ekonomi wilayah Malang. Mendukung gerakan industri kreatif khususnya di bidang kebudayaan dan pariwisata (Departemen Perdagangan RI, 2009), program pengelolaan keragaman nilai budaya dan industri budaya adalah salah satu komitmen yang akan dilakukan untuk mewujudkan industri kreatif nasional. Berdasarkan hal tersebut, diperlukan strategi-strategi untuk mengembangkan industri kerajinan Topeng Malangan khususnya di wilayah Malang sendiri agar eksistensi Topeng Malangan dapat menjadi salah satu aset budaya yang bernilai tinggi serta mendatangkan keuntungan di bidang ekonomi.

Penelitian ini bertujuan untuk merumuskan strategi pengembangan Industri Kecil Menengah (IKM) Topeng Malangan. Penelitian ini juga diharapkan dapat memberikan informasi bagi masyarakat dan gambaran umum sebagai dasar penelitian lebih lanjut mengenai pengembangan IKM Topeng Malangan. Lebih jauh, penelitian ini juga mendukung upaya pelestarian budaya Topeng Malangan serta menjadi bentuk kontribusi nyata di bidang sosial budaya. Rancangan strategi pengembangan industri kerajinan Topeng Malangan dapat mendukung pelestarian serta pengembangan untuk memberikan manfaat baik di bidang ekonomi maupun pariwisata.

Menurut studi pemutakhiran pemetaan industri kreatif Indonesia yang diterbitkan oleh Departemen Perdagangan Republik Indonesia (2009), untuk komitmen yang akan dilakukan oleh Departemen Kebudayaan dan Pariwisata dalam pengembangan industri kreatif nasional tercatat program dan kegiatan untuk pengelolaan 
kekayaan budaya dan program pengembangan nilai budaya serta industri budaya. Hal ini selaras dengan tujuan penelitian ini yakni perancangan strategi untuk mengembangkan industri kerajinan Topeng Malangan.

\section{METODE}

Penelitian ini dilaksanakan di Kabupaten dan Kota Malang dengan melibatkan IKM dan pengrajin Topeng Malangan sebagai objek penelitian. Dibagi dalam 3 tahapan besar, tahap awal penelitian ini berupa studi pustaka yang meliputi penggalian referensi dan penelitian terdahulu yang membahas tentang strategi pengembangan dan pendekatan-pendekatan pengolahan yang dipakai sebagai bentuk pemecahan masalah yang telah dirumuskan.

Tahap kedua adalah tahapan pengumpulan dan pengolahan data. Tahapan pengumpulan data dilakukan sejak Desember 2012-Mei 2013. Pada tahapan pengumpulan data, peneliti merangkum profil IKM Topeng Malangan dan profil paguyuban industri kecil Topeng Malangan. Pemilihan sampel profil dengan menggunakan teknik purposive sampling/judgement sampling, yakni sampel dipilih berdasarkan penilaian peneliti bahwa mereka adalah pihak yang paling baik untuk dijadikan sampel penelitian. Selanjutnya dilakukan studi pembandingan yang diperoleh dari observasi lapangan dan wawancara dengan metode Focus Group Discussion (FGD) yang melibatkan pengrajin, paguyuban, pemerhati budaya, akademisi, pemerintah dan peneliti. Kriteria disusun berdasarkan pada kebutuhan yang mencakup faktor eksternal dan faktor internal. Faktor eksternal meliputi peluang dan ancaman sedangkan faktor internal meliputi kekuatan dan kelemahan. Asumsi dan penilaian personal para ahli yakni pengrajin dan paguyuban serta peneliti sangat memengaruhi pembentukan kriteria. Pertimbangan aspek teknis dan non teknis dalam pembentukan kriteria juga perlu diperhatikan karena juga memengaruhi rumusan strategi. Selain itu, dikumpulkan juga data profil pesaing dan kebijakan-kebijakan pemerintah mengenai Topeng Malangan.
Pengolahan data dengan pendekatan kerangka perumusan strategi yang menggunakan analisis. Dengan SWOT dicari strategi-strategi alternatif bagi pengembangannya. Analisis SWOT adalah metode perumusan strategi yang sangat dasar namun sangat populer karena penggunaannya yang sederhana namun sangat ampuh. Keampuhan tersebut terletak pada kemampuannya menampilkan informasi tentang kondisi gamblang sebuah organisasi. Informasi ini yang kemudian oleh para penentu strategi organisasi digunakan untuk memaksimalkan kekuatan, memanfaatkan peluang, meminimalisasi kelemahan yang terdapat dalam tubuh organisasi, dan menekan dampak ancaman yang timbul dari luar organisasi.

Matriks SWOT adalah ringkasan isu-isu strategis dan kemampuan strategis pada suatu organisasi yang digunakan untuk merumuskan rencana aksi bagi pengembangan organisasi tersebut. Tujuan analisis SWOT adalah untuk mengidentifikasi sejauh mana relevansi faktor-faktor kekuatan, kelemahan organisasi menghadapi perubahan faktor-faktor eksternal organisasi yakni peluang dan ancaman (Johnson dkk., 2011). David (2009) menggunakan matriks SWOT seperti yang tampak pada Gambar 1 untuk mengembangkan empat jenis strategi yakni strategi SO (kekuatan-peluang), strategi WO (kelemahan-peluang), strategi ST (kekuatanancaman), dan strategi WT(kelemahanancaman).

Strategi-strategi yang dihasilkan dari matriks SWOT kemudian dipertajam dengan menggunakan metode Internal Factor Analysis Summary (IFAS) dan Eksternal Factor Analysis

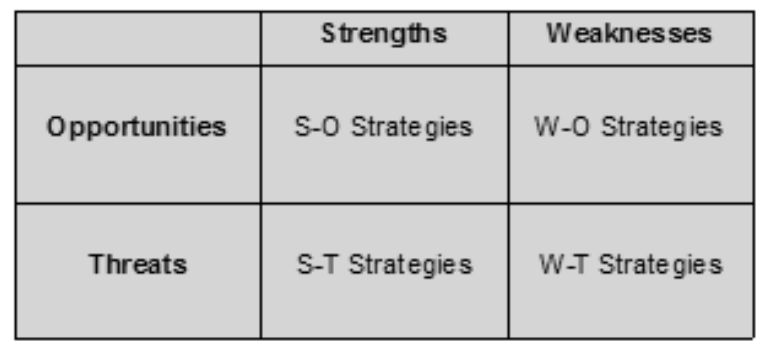

Gambar 1. Matriks SWOT 


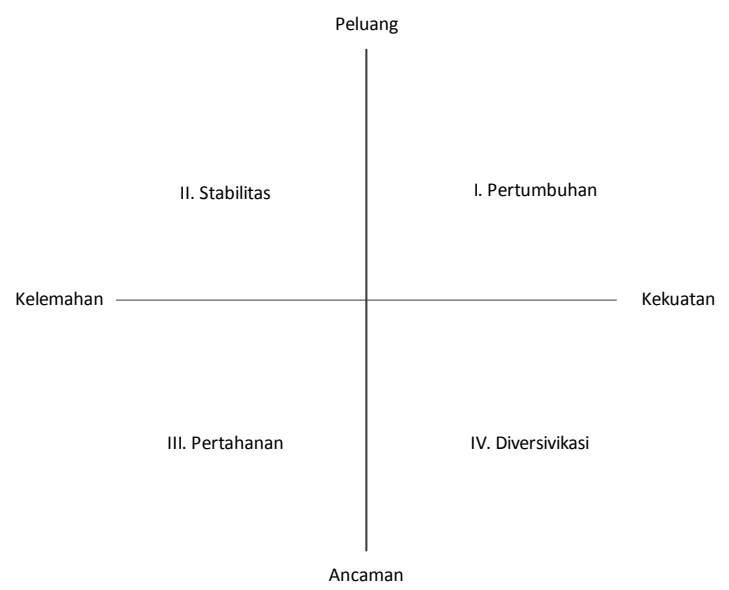

Gambar 2. Diagram Kartesius SWOT

Summary (EFAS). Tahapan dalam menyusun tabel IFAS dan EFAS seperti yang dilakukan oleh Rahmana dkk. (2012) adalah sebagai berikut: (a) menentukan faktor-faktor kekuatan, kelemahan, peluang dan ancaman dari tahap perumusan strategi; (b) memberikan bobot masing-masing faktor dari skala 0 (tidak penting) sampai dengan 1 (sangat penting), di mana semua bobot tersebut jumlahnya tidak melebih skor total 1; (c) Memberikan nilai untuk masing-masing faktor dengan skala mulai dari 1 (di bawah ratarata) sampai dengan 4 (sangat baik); dan (d) menghitung nilai yang merupakan perkalian antara bobot dan nilai.

Nilai akhir dari matriks analisis IFAS dan EFAS kemudian dipetakan dalam Diagram Kartesius SWOT seperti pada Gambar 2. Faktor kekuatan dan peluang diberi nilai positif (+), sedangkan faktor kelemahan dan ancaman diberi nilai (-). Posisi kuadran kemudian menentukan prioritas strategi yang akan dijalankan Rahmana dkk. (2012). Tahapan terakhir adalah tahapan kesimpulan atau tahapan perumusan strategi yang kemudian menjadi rekomendasi strategi yang dapat digunakan sebagai acuan pengambilan keputusan pihak-pihak yang terkait.

\section{HASIL DAN PEMBAHASAN}

Berdasarkan data yang tercatat di Disperindag Kota dan Kabupaten Malang serta koperasi dan UMKM Kota dan Kabupaten Malang, di wilayah ini terdapat sekitar 5 sentra kerajinan Topeng Malangan. Sentra kerajinan Topeng Malangan yang dimaksud di sini adalah IKM dengan produk berupa topeng dalam berbagai ukuran serta produk kerajinan tangan lainnya yang mengambil bentuk Topeng Malangan seperti gantungan kunci, plakat, dan lain-lain. Dengan potensi yang cukup besar ini, maka diperlukan strategi untuk mengembangkan sentra industri Topeng Malangan yang tidak hanya dikerjakan saat menerima pesanan (baik dalam maupun luar negeri) saja, namun dapat dikerjakan secara berkesinambungan. Daya dukung yang dimiliki oleh industri tersebut adalah ketersediaan sumber daya manusia, tata ruang industri, infrastruktur yang cukup baik dan ketersediaan lahan. Disamping pembuatan Topeng Malangan yang masih secara tradisional, pengelolaan pun masih jauh dari sempurna. Untuk itu, strategi penataan ulang terhadap manajemen industri Topeng Malangan sangatlah diperlukan.

Sentra industri Topeng Malangan yang masih aktif yang kemudian dijadikan objek utama penelitian terletak di desa Kedungmonggo, kecamatan Pakisaji dengan nama Sanggar Topeng Asmoro Bangun. Keberadaan kesenian Topeng Malangan di dusun ini sekarang masih terbilang cukup mampu bertahan jika dibandingkan dengan komunitas lain yang berada di wilayah Malang lainnya. Hal ini mungkin didukung oleh letak geografis kawasan Kedungmonggo yang relatif mudah dijangkau oleh konsumen. Namun seiring berjalannya waktu dan memudarnya eksistensi budaya tradisional, sentra industri ini semakin kesulitan untuk mempertahankan keberadaannya.

\section{Analisis Faktor Eksternal}

FGD yang dilakukan berhasil mengidentifikasi faktor-faktor eksternal yang memengaruhi perkembangan IKM Topeng Malangan seperti:

\section{Peluang}

Hasil observasi, FGD, dan diskusi tim peneliti memunculkan beberapa aspek yang dapat menjadi peluang bagi pengembangan IKM Topeng Malangan: 


\section{A. Diversifikasi}

Dari wawancara dengan Bapak Djumadi pengusaha Topeng Malangan Asmoro Bangun di Kedungmonggo, didapat informasi bahwa keseluruhan Topeng Malangan memiliki 65 karakter/motif wajah yang berbeda. Dari 65 karakter/motif topeng ini hanya beberapa karakter yang "populer" di kalangan masyarakat dan pengrajin diantaranya karakter Panji Asmorobangun dan Dewi Sekartaji. Hal ini menunjukan bahwa ragam produk topeng ini masih bisa diperluas. Dari segi jenis produk yang dapat dihasilkan pun masih bisa didiversifikasikan dalam berbagai jenis kerajinan selain hanya sebagai pajangan yang bernilai seni, diantaranya dalam bentuk cinderamata, pernik asesoris, bahkan hingga kerajinan batik dengan motif Topeng Malangan.

Lebih lanjut, kondisi booming pariwisata domestik serta daya tarik pertunjukan seni serta proses pembuatan Topeng Malangan dapat dijadikan momentum bagi diversifikasi jenis kegiatan usaha. Industri pembuatan topeng dapat diperluas menjadi industri pertunjukan seni maupun kampung wisata yang menggelar atraksi pembuatan Topeng Malangan sebagai daya tarik wisata. Dari analisa tersebut maka dapat disimpulkan beberapa diversifikasi yang dapat dilakukan dalam industri kerajinan Topeng Malangan adalah diversifikasi bentuk/ motif, diversifikasi produk, dan diversifikasi jenis kegiatan usaha dengan modifikasi kegiatan pariwisata yang booming.

\section{B. Teknologi Produksi}

Dari sisi produksi, perkembangan teknologi yang cepat saat ini sangat mendukung peningkatan performansi proses produksi. Perkembangan teknologi tepat guna dan penggunaan peralatan yang lebih modern memungkinkan perancangan proses produksi yang lebih efisien, lebih efektif, dan lebih produktif. Perkembangan teknologi memungkinkan penggunaan bahan baku selain kayu, seperti fiberglass ataupun plastik. Penggunaan alternatif bahan baku yang berbeda ini selain mengurangi kesulitan penyediaan bahan baku, dari segi proses produksinya juga memerlukan waktu yang lebih singkat. Dari sisi teknologi produksi, beberapa peluang yang dapat dirumuskan adalah pengembangan Teknologi Tepat Guna (TTG), penggunaan peralatan yang lebih modern, dan diversifikasi bahan baku.

\section{Pasar}

Salah satu peluang paling menjanjikan bagi industri Topeng Malangan adalah peluang pasar. Hingga saat ini, masih banyak segmen pasar yang belum tersentuh ataupun belum dikelola dengan baik oleh industri ini. Penelitian sebelumnya (Melany, 2012) menemukan bahwa pengenalan masyarakat terhadap Topeng Malangan masih sangat rendah. Kedepan, ketika semakin banyak orang yang mengenal Topeng Malangan baik dari pertunjukan seni, pendidikan maupun kampanye budaya, maka dapat dipastikan semakin tinggi pula peluang pasar bagi industri ini.

Lebih jauh lagi, telah teridentifikasi beberapa segmen pasar yang sangat potensial diantaranya penikmat seni yang berada di luar negeri yang selama ini kesulitan untuk mendapatkan akses ke produsen Topeng Malangan. Kemudian saat ini ada kecenderungan lembaga-lembaga pemerintahan dan pendidikan di Malang yang merancang cinderamata khas institusinya dalam bentuk atau motif Topeng Malangan. Jika lembaga-lembaga ini diinventarisir dengan baik, maka akan sangat besar pasar yang dibentuk oleh segmen ini. Segmen wisatawan baik domestik maupun internasional juga dapat menjadi peluang pasar yang menjanjikan. Jika industri ini mampu dikemas dalam konsep wisata budaya yang menarik, kerjasama dengan biro perjalanan wisata nasional maupun internasional dapat dilakukan untuk menarik konsumen pada segmen ini.

Pada akhirnya jika kita berbicara mengenai peluang pasar, tidaklah mungkin kita melupakan perkembangan teknologi informasi di era ini yang mampu memberikan sumbangan yang signifikan bagi perluasan pasar. Sistem organisasi dan 
keterbatasan sumber daya manusia pada industri Topeng Malangan di Malang berakibat pada belum tersentuhnya penggunaan website dan media sosial sebagai strategi pemasarannya. Hal ini akan menjadi peluang untuk secara signifikan memperluas pasar, seperti pasar yang diperkenalkan melalui pertunjukan seni, pendidikan dan kampanye budaya; pasar internasional; lembaga yang memesan Topeng Malangan sebagai cinderamata; konsep industri wisata; kerjasama dengan biro perjalanan wisata; dan penggunaan teknologi informasi dalam pemasaran.

\section{Kearifan Lokal/Kebijakan Pemerintah}

Kecenderungan yang berkembang belakangan ini menunjukkan keinginan besar dari masyarakat untuk menggali dan memberdayakan kearifan lokal. Sebagai salah satu kearifan lokal, Topeng Malangan memiliki peluang besar untuk menjadi ikon budaya Malang. Konsekuensinya, Topeng Malangan akan menjadi tema/motif bagi berbagai jenis produk. Walaupun faktanya, sejak tahun 2000, Pemerintah Kabupaten Malang bisa dianggap tidak lagi secara penuh memperhatikan perkembangan seni, kerajinan dan industri Topeng Malangan. Namun, berdasarkan diskusi dengan Dinas Perindustrian dan Perdagangan Kabupaten Malang, ada rencana Pemerintah Kabupaten Malang untuk kembali memberi perhatian penuh kepada industri kerajinan Topeng Malangan. Sinyalemen pemerintah untuk kembali memberi perhatian pada pengembangan industri kerajinan Topeng Malangan akan sangat mungkin diikuti oleh kebijakan-kebijakan yang mendukungnya diantaranya koordinasi antara dinas-dinas terkait pada Kabupaten Malang seperti Dinas Perindustrian dan Perdagangan, Dinas Pariwisata, Dinas Pendidikan, dan Dinas Kehutanan untuk mendukung pengembangan industri, seni dan budaya Topeng Malangan melalui berbagai aspek seperti edukasi budaya bagi generasi muda di Malang yang kemudian akan lebih meningkatkan pengenalan masyarakat akan Topeng Malangan, pembangunan pariwisata yang mendukung pengenalan budaya Topeng Malangan, pengembangan manajemen dan industri kerajinan Topeng Malangan hingga penyediaan bahan baku bagi produk Topeng Malangan. Lebih jauh, pemerintah dapat memfasilitasi kegiatan-kegiatan yang mendukung pengembangan industri Topeng Malangan, contoh sederhananya industri Topeng Malangan menggunakan sarana promosi produk UMKM milik pemerintah.

\section{E. Pendanaan}

Salah satu kendala utama industri Topeng Malangan adalah masalah dana investasi yang sangat terbatas. Namun kendala ini sebenarnya dapat diatasi dengan mendorong keterlibatan investor swasta ataupun membangun kemitraan dengan pengusaha atau industri besar.

\section{F. Pengembangan Industri Topeng Malangan yang Terintegrasi}

Dari penjabaran berbagai macam peluang bagi pengembangan industri Topeng Malangan semuanya mendukung pengembangan sentra industri Topeng Malangan yang komprehensif dan terintegrasi. Sebenarnya pengembangan sentra industri ini bukanlah sebuah proyek angan-angan belaka sebab faktanya sejak tahun 1982 pemerintah sudah mulai membina dan membangun sebuah kawasan yang diklaim sebagai “desa kerajinan" di dusun Kedungmonggo, Pakisaji. Walaupun pada kenyataaannya saat ini, kawasan ini terbengkalai, namun dengan potensi yang dimilikinya termasuk akses transportasi yang cukup baik untuk sebuah kawasan industri kerajinan maupun wisata, kawasan ini bisa dijadikan sebuah rintisan sentra industri Topeng Malangan. Sekaligus sebagai bagian dari pemberdayaan ekonomi masyarakat di dalam maupun di sekitar kawasan ini.

\section{Ancaman}

Berikut adalah ancaman-ancaman yang bisa mengganggu keberadaan IKM Topeng Malangan: 


\section{A. Idealisme Pengrajin}

Topeng adalah hasil dari kerajinan tangan atau kriya sedangkan tari adalah gerak dalam cerita dan nada. Namun, idealisme yang diambil oleh seorang pengrajin Topeng Malangan adalah bahwa tari dan Topeng Malangan tidak dapat dipisahkan. Idealisme tersebut dirasakan sangat penting bahkan cenderung disakralkan. Banyak penopeng yang juga menguasai tari dan musik karawitan dari tarian tersebut dan tentunya dengan jalan cerita yang lengkap. Seorang penopeng harus dapat menjiwai topengnya sejak awal ia membuat bakal topeng sehingga saat menari, sang penopeng benar-benar menjiwai tarian tersebut dan karakter topeng tersebut. Hal ini menyebabkan mereka sangat idealis dengan ciptaannya.

Berkaitan dengan kepentingan industri, tentunya idealisme tersebut tidak bisa sepenuhnya dipenuhi. Ada beberapa kepentingan idealisme yang harus dikorbankan untuk memenuhi tuntutan industri. Seperti dalam proses pembuatan Topeng Malangan, bahan baku utama yang digunakan adalah kayu. Namun, bila terdesak waktu dan harga, bahan alternatif penggantinya adalah fiber. Hal ini menyebabkan nilai-nilai kesakralan sebuah Topeng Malangan menurun. Namun di lain pihak, hal ini sangat menguntungkan industri Topeng Malangan. Selain itu, bahan fiber tidak terlalu mahal. Oleh sebab itu, harga jual Topeng Malangan dari fiber tidak semahal dari kayu.

\section{B. Pengambilan Keuntungan oleh Pihak Ketiga}

Ancaman lain adalah munculnya beberapa pihak yang mengaku sebagai Event Organizer (EO) yang sebenarnya tidak tahu persis bagaimana cara pembuatan Topeng Malangan namun mereka mengambil keuntungan dari produk hasil kerajinan Topeng Malangan maupun wisata seni dan industrinya. Bahkan ironinya, mereka bisa mengambil keuntungan hampir 100\% dari harga pokok sebuah Topeng Malangan. Sebenarnya, kehadiran EO ini akan sangat menguntungkan pengrajin apabila dibuat semacam jejaring pemasaran Topeng Malangan dan terkoordinasi dengan baik. Hingga saat ini, kehadiran EO tersebut hanya sebatas bila ada permintaan. Pihak pengrajin pun hanya sebatas menerima pesanan dan kemudian menyetorkan ke pihak EO.

\section{Dukungan Pemerintah yang tidak Terorganisasi dengan Baik}

Dukungan dari pemerintah sempat terlihat di era kejayaan Topeng Malangan. Namun sayangnya, tidak stabil. Hal ini yang menyebabkan nafas pengrajin seolah kembang kempis dan menanti harapan yang tak kunjung pasti. Saat pemerintah memiliki program, pengrajin benarbenar didukung. Sayangnya, selama ini program hanya untuk kepentingan sesaat seperti pameran budaya, mengisi acara pemerintahan, dan belum ada program semacam pendampingan secara berkelanjutan agar keberadaan pengrajin Topeng Malangan lebih stabil. Kepentingan pemerintah pun terkadang tumpang tindih. Dalam artian, kurang terkoordinasi dengan baik antara pemerintah daerah, dinas perindustrian, dinas pendidikan ataupun dinas pariwisata.

\section{Paten oleh Pihak Lain}

Ancaman lain yang bisa muncul adalah masalah hak paten apakah kota Malang atau kabupaten Malang yang sebaiknya mengakui kepemilikan Topeng Malangan. Kota dan kabupaten Malang masih sama-sama terlena dan belum menyadari aset budaya yang terkandung dalam sebuah mahakarya Topeng Malangan.

\section{E. Kepunahan Seni dan Tradisi Topeng Malangan}

Kajian terhadap realita perjalanan dan nasib kesenian yang ada di Indonesia, menunjukkan bahwa nasib kesenian diambang kepunahan. Termasuk Topeng Malangan yang semakin lama ditinggalkan dan bisa saja hanya menjadi sebuah nama. Sekarang tinggal bagaimana masyarakat menyiasati kondisi ini yang tentu saja semua 
tidak sepenuhnya menjadi tanggung jawab pemerintah, tetapi kita, masyarakat yang peduli dan mau mempedulikan nasib kesenian Topeng Malangan agar tidak menjadi fatamorgana.

\section{Analisis Faktor Internal}

\section{Kekuatan}

Beberapa aspek yang menjadi kekuatan IKM Topeng Malangan adalah:

\section{A. Nilai Budaya}

Dari beberapa faktor-faktor kekuatan tersebut, dapat dilihat bahwa Topeng Malangan adalah salah satu karya seni rupa yang bernilai tinggi. Karena, nilai-nilai yang terkandung di dalam Topeng Malangan terbentuk dari warisan budaya leluhur. Nilai budayanya semakin tinggi karena warisan tersebut terus dipelihara dan dilestarikan. Sepanjang tahun 1980-an hingga tahun 1990-an perhatian masyarakat dan juga instansi pemerintah dan swasta sangat besar. Sejak tahun 1990-an, perkembangan wayang topeng di dusun Kedungmonggo seringkali dinyatakan oleh pemda kabupaten Malang sebagai aset daerah.

\section{B. Ketersediaan Bahan Baku}

Proses pembuatan Topeng Malangan memakan waktu tiga hari hingga satu bulan. Bahan baku yang digunakan adalah kayu pule, mentaos, nangka, cangkrik, dan basiah. Adapun jenis-jenis kayu tersebut mudah didapat di sekitar desa Pakisaji. Proses pembuatannya sangat rinci, bahkan proses pewarnaan pun masih menggunakan zat warna alami dari tumbuhtumbuhan.

\section{Tidak memiliki Pesaing}

Topeng Malangan adalah karya seni yang tinggi dengan detail pengerjaan yang rumit, dapat dikatakan bahwa produk ini tidak memiliki pesaing. Tidak banyak orang yang memproduksi Topeng Malangan serta tidak banyak juga orang yang membelinya. Topeng Malangan bukanlah kebutuhan primer yang wajib dipenuhi melainkan sebuah karya seni yang bernilai tinggi dan hanya orang-orang di kalangan tertentu yang berminat untuk membeli. Banyak orang membeli Topeng Malangan dan merasa puas karena bisa merasakan keindahan di setiap ukirannya.

\section{Kepedulian dari Banyak Pihak}

Eksistensi Topeng Malangan di kota Malang sendiri masih kurang, dalam artian belum banyak orang yang mengenal keberadaan Topeng Malangan. Bahkan di kalangan orang Malang sekalipun, karya Topeng Malangan tidaklah setenar keripik tempe atau apel Batu. Namun, banyak orang yang memberi perhatian akan hal ini. Khususnya di kalangan akademisi, beberapa penelitian yang bertemakan Topeng Malangan cukup banyak ditemukan. Para pengusaha yang mau menanamkan modal dalam pembuatan topeng pernah ada, meskipun tidak banyak. Peran budayawan dalam melestarikan Topeng Malangan juga tidak perlu diragukan lagi. Melalui koleksi serta pemahaman akan setiap karakter Topeng Malangan yang mengandung filosofi tinggi, serta beberapa aktivitas pameran yang digelar atau sekedar tari penyambutan Topeng Malangan, sudah mengangkat keberadaan akan Topeng Malangan. Saat ini, banyak restoran yang sengaja menggelar atraksi tari Topeng Malangan untuk menarik pengunjungnya. Selain menikmati seni tari, pengunjung juga bisa membeli langsung karya seni Topeng Malangan. Bahkan, beberapa hotel di Malang sudah melengkapi desain interior dengan nuansa Topeng Malangan. Hal ini menunjukkan kegiatan pelestarian budaya Topeng Malangan masih berlangsung sampai saat ini.

\section{Kelemahan}

Beberapa kelemahan yang dimiliki IKM Topeng Malangan adalah:

\section{A. Standarisasi Produk}

Seiring dengan perkembangan zaman menjadikan pertumbuhan industri Topeng 
Malangan semakin menurun. Selama ini standarisasi terhadap produk Topeng Malangan juga belum dijalankan, sehingga kualitas dari produk tersebut masih bervariasi antara pengrajin yang satu dengan pengrajin yang lain.

\section{B. Semakin terbatasnya Sumber Daya Manusia}

Saat ini banyak pengrajin yang beralih profesi menjadi buruh tani, pekerja bangunan, pekerja pabrik dan lain-lain. Hal ini disebabkan pengrajin sudah merasa jenuh dengan pekerjaan mereka serta adanya idealisme para pengrajin bahwa membuat Topeng Malangan merupakan suatu budaya dan seni, bukan mata pencaharian. Kurangnya kesadaran generasi muda dalam melestarikan budaya Topeng Malangan juga sangat mengkhawatirkan akan kelangsungan industri Topeng Malangan, karena mereka cenderung mencintai budaya asing. Menurut Melany (2012) bahwa 50\% generasi muda di Malang tidak mengenal Topeng Malangan. Hal inilah yang menyebabkan pertumbuhan industri Topeng Malangan semakin meredup, karena sekarang saja banyak masyarakat Malang yang tidak mengenal akan Topeng Malangan.

\section{Manajemen yang Sangat Lemah}

Dari sudut pengelolaan usaha, industri Topeng Malangan juga mengalami banyak kendala. Secara organisasi, industri Topeng Malangan juga belum dikelola dengan baik, karena rata-rata latar belakang pendidikan pengrajin adalah SMP, bahkan ada juga yang tidak tamat SD. Sumber daya manusia yang unggul juga dibutuhkan dalam mengelola industri ini, karena tanpa adanya SDM yang berkualitas sangat sulit untuk mempertahankan Topeng Malangan. Hal itu sangat dibutuhkan untuk melakukan perbaikan proses produksi, pengelolaan keuangan serta pemasaran. Data pengrajin yang dimiliki oleh pemerintah juga banyak yang tidak sama dengan di lapangan, artinya sudah banyak pengrajin yang gulung tikar. Namun pemerintah belum melakukan pendataan ulang, sehingga jika ada seseorang yang ingin mencari data pengrajin
Topeng Malangan akan sangat terbantu dengan data tersebut.

Belum ada pembagian tugas yang jelas antara pekerja yang satu dengan yang lain dalam pengerjaan Topeng Malangan. Selain itu belum ada standar terhadap proses pengerjaan, sehingga orang yang ingin belajar membuat topeng maka harus mencari informasi kepada pengrajin yang sudah pengalaman dan mereka juga hanya sebatas pengetahuan di dalam otak dan tidak tertulis. Ditambah lagi proses produksi yang dilakukan sekarang masih bersifat tradisional, dengan menggunakan alat tatah yang dipesan dari pandai besi dan peralatan lain yang sederhana termasuk gergaji tangan dan palu untuk membentuk topeng. Padahal peralatan yang lebih canggih sudah banyak beredar di pasaran.

\section{Perhatian Pemerintah}

Perhatian pemerintah selama ini juga sangat rendah, karena hampir sepuluh tahun terakhir pemerintah tidak melakukan pendampingan terhadap pengrajin. Padahal Topeng Malangan merupakan ikon Kabupaten Malang yang harus dikembangkan. Sehingga tanpa dukungan pemerintah, para pengrajin juga akan kesulitan dalam mempertahankan Topeng Malangan. Luasnya wilayah Kabupaten Malang juga merupakan kendala yang dihadapi oleh pemerintah dalam melakukan pendampingan serta kesulitan dalam melakukan penataan terhadap industri Topeng Malangan.

\section{E. Keterbatasan Modal}

Modal merupakan kendala yang dihadapi oleh para pengrajin, karena untuk membuat Topeng Malangan dibutuhkan bahan kayu serta upah harian. Selama ini mereka hanya membuat topeng dalam jumlah sedikit, kadang ada juga yang membuat topeng berdasarkan pesanan. Sehingga kalau ada pesanan dalam jumlah besar, mereka tidak bisa memenuhinya karena waktu yang dibutuhkan untuk membuat 1 topeng adalah 3 hari. 
Tabel 1. Analisis SWOT

\section{KEKUATAN}

1. Mempunyai nilai budaya yang tinggi

2. Kearifan lokal menjadi tren

3. Kejayaan masa lalu, era Mbah Karimun

4. Sumber daya manusia yang paham betul akan Topeng Malangan

5. Setiap orang bisa belajar untuk menjadi pengrajin

6. Bahan baku mudah didapat

7. Banyak orang yang peduli terhadap Topeng Malangan diantaranya akademisi, pengusaha, dan budayawan.

8. Ada kegiatan yang dibuat untuk memperkenalkan Topeng Malangan sebagai khas budaya Malang

9. Tidak adanya pesaing

10. Aksesibiltas memadai (lokasi)

11. Sudah ada rintisan sentra indutri kerajinan Topeng Malangan di dusun Kedungmonggo, Pakisaji

12. Kegiatan pariwisata yang booming

13. Adanya rencana Pemerintah Kabupaten Malang melalui DISPERINDAG untuk kembali melakukan pembinaan bagi kelompok kerajinan Topeng Malangan.

\section{KELEMAHAN}

1. Tidak ada masyarakat yang profesi utamanya adalah pengrajin Topeng Malangan

2. Kejenuhan dari pengrajin

3. Menurunnya jumlah pengrajin Topeng Malangan

4. Idealisme pengrajin, yang hanya menitikberatkan pada budaya

5. Prinsip hidup yang sederhana dan tidak memiliki target dalam hidup

6. Idealisme bahwa seorang pengrajin harus bisa menjadi penari dan mengerti tentang filosofi Topeng Malangan

7. Kurangnya minat menjadi pengrajin

8. Perpecahan antar pengrajin, terutama keluarga maestro (Kompas, 23 Februari 2013)

9. Tidak ada paguyuban pengrajin Topeng Malangan

10. Tidak adanya pembagian kerja yang jelas dalam memproduksi Topeng Malangan

11. Belum adanya organisasi dan manajemen produksi, pemasaran, dan keuangan yang baik

12. Keberadaan event organiser wisata Topeng Malangan tanpa kordinasi dengan pengrajin

13. Keterbatasan modal

14. Sistem penggajian yang tidak pasti

15. Proses produksi masih tradisional

16. Belum adanya standarisasi industri Topeng Malangan

17. Sentra industri Topeng Malangan tidak berfungsi lagi

18. Hanya ada 3 tempat pengrajin yaitu, Pakisaji, Tumpang, dan Jambuwer

19. Minimnya kesadaran generasi muda dalam pelestarian budaya

20. Kurangnya perhatian pemerintah

21. Ketidaklengkapan data pengrajin dari Disperindag

22. Minimnya dalam mengikuti pameran

23. Proses, karakter dan jaringan pemasaran belum terdokumentasikan dengan baik.

24. Lemahnya sistem pemasaran

25. Pasar tidak stabil

26. Topeng Malangan merupakan sebuah budaya, bukan kebutuhan

27. Keberadaan Topeng Malangan belum dikenal luas oleh masyarakat Malang

28. Belum adanya komunikasi dan kerja sama yang baik antara pemerhati Topeng Malangan

\section{PELUANG}

1. Diversifikasi bentuk/motif.

2. Diversifikasi produk

3. Diversifikasi jenis kegiatan usaha.
1. Diversifikasi motif dan produk 1. Meningkatkan pendapatan pengrajin (W1, dengan teknologi yang modern (S1, $\mathrm{S} 2, \mathrm{~S} 3, \mathrm{~S} 4, \mathrm{~S} 6, \mathrm{O} 1, \mathrm{O} 2, \mathrm{O} 4, \mathrm{O} 5, \mathrm{O} 6$

2. Melatih generasi muda dalam 2. Merancang organisasi dan manajemen (W8, membuat topeng ( $\mathrm{S} 1, \mathrm{~S} 2, \mathrm{~S} 5$, O1, $\mathrm{O} 2, \mathrm{O} 3)$

\section{WO}

W2, W3, W4, W5, W6, W7, W14, O1, O2, O3,O7, 08, 09, O11, O12

W9, W10, W11, W12, W13, W14, O10, O11, O18) 
4. Pengembangan teknologitepat 3. Merancang sentra indutri 3. Optimasi proses produksi pembuatan guna

5. Penggunaan peralatan yang lebih modern

6. Diversifikasi bahan baku

7. Pasar yang diperkenalkan melalui pertunjukan seni, pendidikan dan kampanye budaya.

8. Pasar internasional

9. Lembaga yang memesan Topeng Malangan sebagai cinderamata

10. Konsep industri wisata

11. Kerja sama dengan biro perjalanan wisata

kerajinan Topeng Malangan yang komporehensif dan terintegrasi di 4 . Dusun Kedungmonggo, Pakisaji (S7, S8, S10, S11, O7, O9, O10, O11, O13)

4. Memanfaatkan teknologi informasi dalam pemasaran (S8, S12, O8, 012)

5. Melakukan kerjasama dengan pemerintah daerah (S13, O10, 014)

6. Membangun industri wisata yang bersinergi dengan produksi Topeng Malangan (S1, S2, S10, S11, S12, O7, O8, O1, O11, O12, O13, O16, O17, O18, 019)

12. Penggunaan teknologi informasi dalam pemasaran

13. Menjadikan Topeng Malangan sebagai Ikon Malang

14. Koordinasi antar dinas terkait (Dinas Perindustrian dan Perdagangan, Dinas Pariwisata, Dinas Kehutanan, Dinas Pendidikan)

15. Pemanfatan Fasilitas pemerintah untuk pengembangan industri Topeng Malangan. Contohnya: sarana promosi produk UMKM milik pemerintah yang bisa digunakan, yaitu di Desa Bedali Singosari dan Singosari

16. Keterlibatan investor swasta

17. Kemitraan dengan pengusaha besar

18. Pengembangan sentra industri Topeng Malangan yang komprehensif dan terintegrasi

19. Memberdayakan masyarakat sekitar

\section{ANCAMAN}

7. Ekspansi pasar (S9, O9, O11, O12)
Topeng Malangan (W15, W16, O4, 05, O6)

4. Merancang sentra indutri kerajinan Topeng Malangan yang komporehensif dan terintegrasi di Dusun Kedungmonggo Pakisaji (W17, W18, O10, O11, O18)

. Memasukkan Topeng Malangan dalam muatan lokal di sekolah (W19, W20, O7, O13, O14)

6. Melibatkan pemerintah daerah (W20, W21, O14, O15)

7. Membangun strategi pemasaran yang baik (W22, W23, W24, W25, W26, W27, O9, O11, O12,)

8. Membuat forum pemerhati Topeng Malangan (W28, O7, O13, O17)

1. Topeng Malangan dipatenkan 1. Mematenkan Topeng Malangan 1. Merancang sentra indutri kerajinan oleh pemerintah kabupaten lain sebagai ikon Kab Malang $(\mathrm{S} 1, \mathrm{~S} 2, \mathrm{~S} 3, \mathrm{~S} 4, \mathrm{~T} 1)$

2. Punah/dilupakan oleh masyarakat 2. Melestarikan Topeng Malangan (S1,S2,S3,S4,S,T2) Topeng Malangan yang komporehensif dan terintegrasi di Dusun Kedungmonggo Pakisaji (W17,W18,T1,T2)

2. Memasukkan Topeng Malangan dalam muatan lokal di sekolah (W19,W20,T2)

3. Melibatkan pemerintah daerah (W20,W21,T1,T2)

4. Membuat forum pemerhati Topeng Malangan (W28,T2) 


\section{F. Kendala Pemasaran}

Selama ini pemasaran merupakan kendala utama yang dihadapi oleh pengrajin. Banyak pengrajin yang beralih profesi. Hal itu dilakukan karena setiap tahun permintaan topeng semakin menurun, padahal mereka membutuhkan uang untuk menghidupi keluarga mereka. Sistem pemasaran tradisional yang mengandalkan pembeli yang datang ke tempat pengrajin merupakan kendala yang dihadapi dalam sistem pemasaran. Karena seiring perkembangan teknologi informasi, calon konsumen sebenarnya bisa mencari informasi Topeng Malangan melalui internet. Sedangkan para pengrajin rata-rata belum bisa memanfaatkan teknologi untuk memasarkan produk mereka. Hal itu juga diperburuk dengan kurangnya minat pengrajin dalam mengikuti pameran yang dilakukan baik oleh pemerintah maupun swasta. Karena banyak masyarakat Malang yang belum mengetahui Topeng Malangan, apalagi masyarakat di luar Malang. Padahal tujuan mengikuti pameran adalah untuk mengenalkan Topeng Malangan kepada masyarakat umum serta menarik para pengunjung untuk membeli Topeng Malangan sebagai oleh-oleh khas Malang. Di sisi yang lain, Topeng Malangan merupakan sebuah seni, sehingga pengrajin juga mengalami kesulitan dalam memasarkannya. Karena hanya orang pecinta seni yang akan membeli dan mengoleksi Topeng Malangan.

\section{Analisis SWOT}

Dari identifikasi faktor-faktor eksternal dan internal, kemudian dibuatlah analisis kekuatan, kelemahan, peluang dan ancaman. Dari analisis SWOT untuk faktor-faktor internal maupun eksternal dengan menggunakan strategi SO, strategi WO, strategi ST, dan strategi WT, digenerasikan strategi-strategi pengembangan industri Topeng Malangan seperti pada Tabel 1, yang kemudian bisa disimpulkan menjadi 13 strategi sebagai berikut: (1) Merancang organisasi dan manajemen usaha yang baik; (2) Merancang sentra industri kerajinan Topeng Malangan yang komporehensif dan terintegrasi di dusun Kedungmonggo, Pakisaji; (3) Membangun industri wisata yang bersinergi dengan produksi Topeng Malangan; (4) Membangun strategi pemasaran yang baik, termasuk dengan memanfaatkan teknologi informasi; (5) Ekspansi Pasar; (6) Optimasi proses produksi pembuatan Topeng Malangan; (7) Diversifikasi motif dan produk dengan teknologi yang modern; (8) Meningkatkan pendapatan pengrajin; (9) Memasukkan Topeng Malangan dalam muatan lokal di sekolah; (10) Membuat forum pemerhati Topeng Malangan; (11) Melestarikan Topeng Malangan; (12) Mematenkan Topeng Malangan sebagai ikon Kabupaten Malang; dan (13) Melibatkan pemerintah daerah. 


\section{Prioritas Strategi}

Dari ketigabelas strategi yang dirumuskan berdasarkan analisis faktor internal dan faktor eksternal kemudian ditentukan strategi-strategi prioritas yang sesuai dengan kondisi IKM Topeng Malangan saat ini. Semua faktor kekuatan, kelemahan, peluang dan ancaman dianalisis lagi dengan menggunakan matrik IFAS dan matriks EFAS. Seluruh faktor eksternal maupun internal kemudian diberi bobot, rating dan nilai untuk menentukan posisi dan kondisi IKM saat ini dan strategi-strategi apa yang harus menjadi prioritas bagi pengembangan IKM dalam kondisi saat ini.

Tabel 2. Matriks Internal Factors Analysis Summary

\begin{tabular}{llccc}
\hline \multicolumn{1}{c}{ Faktor Internal } & Bobot & Rating & Nilai \\
\hline & Kekuatan & & & \\
1 & Nilai budaya & 0,08889 & 3 & 0,26667 \\
2 & Ketersediaan bahan baku & 0,1111 & 4 & 0,44444 \\
3 & Tidak memiliki pesaing & 0,13333 & 4 & 0,53333 \\
4 & Kepedulian dari banyak pihak & 0,02222 & 3 & 0,06667 \\
& Sub Total & 0,356 & & 1,311 \\
& Kelemahan & & & \\
5 & Standarisasi produk & 0,06667 & 1 & 0,06667 \\
6 & Ketidaktersediaan SDM & 0,17778 & 2 & 0,35556 \\
7 & Manajemen yang sangat lemah & 0,15556 & 1 & 0,15556 \\
8 & Rendahnya perhatian pemerintah & 0,04444 & 1 & 0,04444 \\
9 & Keterbatasan modal & 0,02222 & 1 & 0,02222 \\
10 & Kendala pemasaran & 0,17778 & 1 & 0,17778 \\
& Sub Total Total & 0,644 & & 0,822 \\
& $\quad 1$ & & 2,133 \\
\hline
\end{tabular}

Tabel 3. Matriks External Factors Analysis Summary

\begin{tabular}{llccc}
\hline \multicolumn{1}{c}{ Faktor Eksternal } & Bobot & Rating & Nilai \\
\hline Peluang & & & \\
1 & Difersifikasi & 0,16364 & 1 & 0,16364 \\
2 & Perkembangan teknologi & 0,14545 & 1 & 0,14545 \\
3 & Pasar & 0,18182 & 1 & 0,18182 \\
4 & Kearifan lokal/ kebijakan pemerintah & 0,10909 & 2 & 0,21818 \\
5 & Pendanaan oleh sektor swasta & 0 & 1 & 0 \\
6 & $\begin{array}{l}\text { Pengembangan yang terintegrasi } \\
\text { Sub Total }\end{array}$ & 0,12727 & 1 & 0,12727 \\
& 0,727 & & 0,836 \\
7 & & & \\
8 & $\begin{array}{l}\text { Ancamam } \\
\text { Pengambilan keuntungan oleh pihak }\end{array}$ & 0,03636 & 4 & 0,14545 \\
& ketiga & 0,07273 & 3 & 0,21818 \\
9 & $\begin{array}{l}\text { Dukungan pemerintah yang tidak } \\
\text { terkoordinasi }\end{array}$ & 0,09091 & 3 & 0,27273 \\
10 & Paten oleh pihak lain & 0,01818 & 1 & 0,01818 \\
11 & Kepunahan seni dan tradisi topeng & 0,05455 & 1 & 0,05455 \\
& Malangan & 0,273 & & 0,709 \\
& Sub Total $\quad$ Total & 1 & & 1,545 \\
\hline
\end{tabular}


Hasil analisis dengan menggunakan matriks IFAS pada Tabel 1 memberikan nilai 1,311 untuk faktor kekuatan dan nilai 0,822 untuk nilai kelemahan. Selisih kedua nilai ini adalah 0,489. Sementara itu analisis dengan menggunakan matriks EFAS pada Tabel 2 menghasilkan nilai 0,836 untuk faktor peluang dan nilai 0,822 untuk faktor ancaman. Dari kedua nilai ini didapat selisih sebesar 0,127 . Kedua nilai selisih ini kemudian diplot dalam diagram kartesius SWOT sebagai nilai X dan nilai Y. Plotting kedua nilai tersebut pada diagram kartesius seperti tampak pada Gambar 3, dimana menghasilkan sebuah titik yang berlokasi di kuadran I. Hal ini berarti bahwa strategi pengembangan IKM Topeng Malangan akan lebih dikonsentrasikan pada proses pertumbuhan organisasi, atau dengan kata lain strategi akan diprioritaskan pada strategi SO yakni strategi dengan mempergunakan semua kekuatan organisasi untuk memanfaatkan peluang yang ada.

Sama dengan hasil yang ditunjukkan pada diagram kartesius SWOT, perhitungan nilai strategi kuantitatif seperti yang ditunjukkan pada Tabel 3. juga menunjukkan bahwa nilai strategi SO $(2,147)$ merupakan nilai tertinggi apabila dibandingkan dengan nilai strategi-strategi lain yaitu WO $(1,658)$, ST $(2,020)$ dan WT $(1,531)$.

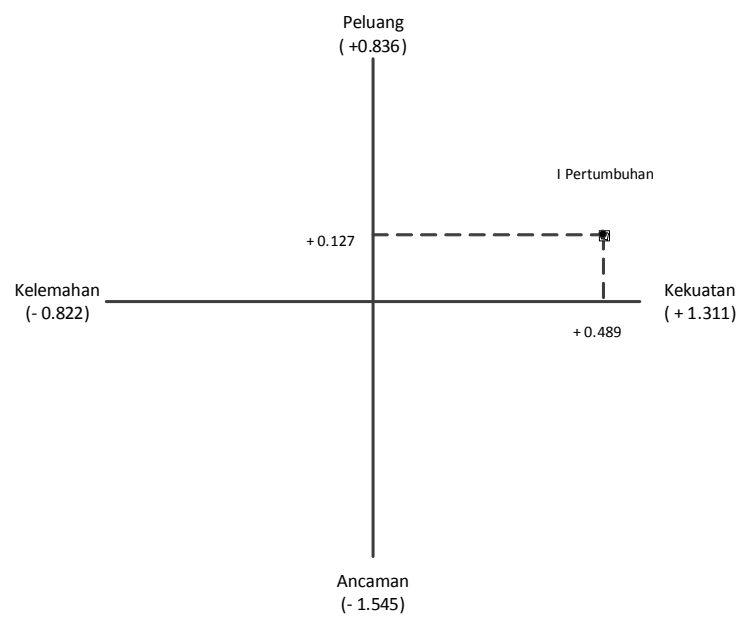

Gambar 3. Analisis Kartesius SWOT
Tabel 4. Kombinasi Strategi Kuantitatif

\begin{tabular}{|c|c|c|}
\hline $\begin{array}{l}\text { IFAS } \\
\text { EFAS }\end{array}$ & Strength (S) & Weakness (W) \\
\hline \multirow{3}{*}{$\begin{array}{l}\text { Opportunity } \\
\text { (O) }\end{array}$} & $\mathrm{SO}$ & WO \\
\hline & $=1,311+0,836$ & $=0,822+0,836$ \\
\hline & $=2,147$ & $=1,658$ \\
\hline \multirow[t]{3}{*}{ Threat $(\mathrm{T})$} & ST & WT \\
\hline & $=1,311+0,709$ & $=0,822+0,709$ \\
\hline & $=2,02$ & $=1,531$ \\
\hline
\end{tabular}

Seperti yang telah dihasilkan sebelumnya dalam tahapan proses perumusan strategi berdasarkan SWOT, terdapat 13 strategi yang bisa digunakan untuk mengembangkan IKM Topeng Malangan. Ketigabelas strategi ini dihasilkan dari strategi SO, WO, ST, dan WT. Hasil analisis lebih lanjut menyarankan prioritas strategi hanya pada strategi SO atau konsentrasi pada pertumbuhan organisasi, maka perumusan strategi ini dispesifikasikan menjadi 6 strategi yang menggunakan kekuatan untuk memanfaatkan peluang yang ada saat ini. Keenam strategi tersebut adalah: 1) Merancang sentra industri kerajinan Topeng Malangan yang komprehensif dan terintegrasi di Dusun Kedungmonggo, Pakisaji; (2) Membangun industri wisata yang bersinergi dengan produksi Topeng Malangan; (3) Membangun strategi pemasaran yang baik, termasuk dengan memanfaatkan teknologi informasi; (4) Ekspansi Pasar; (5) Diversifikasi motif dan produk dengan teknologi yang modern; (6) Melibatkan pemerintah daerah.

Pembangunan sebuah sentra industri kerajinan dan wisata Topeng Malangan yang komprehensif dan terintegrasi serta melibatkan masyarakat dalam jumlah yang lebih banyak diperlukan agar IKM ini memiliki gaung dan berdampak bagi masyarakat. Untuk itu, bekas sentra industri kerajinan di Dusun Kedungmonggo, Pakisaji dapat direstrukturisasi kembali. Banyak alasan kenapa tempat ini yang dipilih, pertama karena kerajinan Topeng Malangan sendiri berawal dari dusun ini, di 
tempat ini tinggal keluarga pengrajin yang masih memiliki keahlian sebagai pengrajin dan memahami filosofis kultural maupun teologis Topeng Malangan. Selain itu dusun Pakisaji memiliki aksesibilitas yang memadai dan pernah menjadi menjadi sentra kerajinan di tahun 1990-an membuatnya lebih mudah untuk dirintis kembali. Masyarakat yang berdiam di wilayah tersebut juga kebanyakan tidak memiliki pekerjaan tetap sehingga dapat diberdayakan lewat sentra industri kerajinan ini.

Sebuah peluang lain yang dapat dipergunakan adalah boomingnya pariwisata di Indonesia khususnya di Malang di samping kearifan lokal yang menjadi tren saat ini. Strategi yang dapat dilakukan adalah mengintegrasikan industri kerajinan dengan industri wisata. Sentra industri kerajinan dan wisata Topeng Malangan yang terintegrasi bukan saja menarik bagi pembeli barang seni tapi juga dapat digunakan untuk menarik wisatawan baik dalam maupun luar negeri yang tertarik dengan sejarah, budaya, filosofi dan bahkan pada proses pembuatan Topeng Malangan. Biro perjalanan wisata dapat diajak bekerjasama untuk mempromosikan industri wisata ini bagi wisatawan khususnya yang berkunjung ke Malang.

Peluang pasar bagi produk Topeng Malangan sebagai kerajinan maupun objek wisata terbuka sangat luas apalagi jika Topeng Malangan bisa dijadikan sebuah ikon budaya. Namun, strategi pemasaran dan promosi harus menjadi salah satu aspek yang perlu dibangun. Perkembangan teknologi informasi modern saat ini membuka peluang untuk menjangkau pasar yang lebih luas. Pembuatan situs online atau penggunaan media sosial akan sangat mendukung ekspansi pasar. Saat ini saja, sebut saja peminat seni dari luar negeri dan institusi-institusi pendidikan maupun pemerintahan yang membutuhkan cinderamata khas Malang yang masih kesulitan dalam proses pemesanan produk ini. Dengan teknologi internet, pasar dan konsumen bisa terus dijangkau dan diperluas.

Dengan teknologi modern saat ini juga, bisa dilaksanakan diversifikasi motif kerajinan dan jenis produk sehingga dapat memenuhi keinginan pasar. Diversifikasi motif misalnya dengan mengeksplorasi seluruh motif karakter topeng yang saat ini belum tersentuh. Dari segi jenis produk dapat dilakukan pengembangan produk sehingga menambah jenis-jenis produk dan tidak terbatas pada benda kerajinan seni saja

Proses mematenkan Topeng Malangan adalah langkah yang harus segera dilakukan oleh pemerintah daerah. Topeng Malangan merupakan salah satu produk khas yang menjadi salah satu ikon yang dimiliki oleh Kabupaten Malang. Tetapi sampai saat ini, Topeng Malangan belum dipatenkan oleh pemerintah Kabupaten Malang. Kalau hal ini terus dibiarkan, maka tidak menutup kemungkinan daerah lain atau bahkan negara lain akan mematenkan Topeng Malangan. Seperti Reog Ponorogo yang sempat diklaim oleh Malaysia sebagai budaya Malaysia. Berdasarkan pengalaman tersebut, sebaiknya Pemerintah Kabupaten Malang segera mematenkan Topeng Malangan sebagai ikon daerah untuk menghindari klaim bahwa Topeng Malangan adalah produk khas daerah lain. Setelah adanya pengakuan secara hukum oleh pemerintah, maka Topeng Malangan akan mudah untuk dikembangkan.

Dukungan pemerintah daerah sangat diharapkan oleh para pengrajin Topeng Malangan, sehingga keterlibatan pemerintah dalam bentuk pendampingan-pendampingan sangat diperlukan. Pendampingan yang terus menerus oleh pemerintah daerah terhadap para pengrajin, baik berupa pembinaan manajemen IKM Topeng Malangan yang selama ini masih bersifat tradisional, melakukan pendampingan proses produksi dengan memberikan bantuan peralatan yang lebih modern dengan kegiatan kemitraan, melakukan pembinaan pemasaran melalui pamanfaatan teknologi informasi serta melakukan kebijakan yang berpihak kepada para pengrajin. Jika hal tersebut dilakukan oleh pemerintah daerah, maka kelangsungan produk Topeng Malangan bisa diharapkan bahkan bisa berkembang menjadi sangat pesat seperti halnya dengan topeng Bali yang menjadi incaran para 
wisatawan. Para pengrajin juga akan lebih bersemangat dalam membuat topeng serta para pemuda yang belum memiliki pekerjaan akan mencoba menjadi pengrajin sebagai mata pencahariannya.

\section{SIMPULAN}

Setelah mengidentifikasi faktor-faktor internal dan eksternal IKM Topeng Malangan serta menganalisisnya dengan menggunakan matrix SWOT, IFAS dan EFAS, maka dihasilkan prioritas strategi yang dapat diterapkan untuk pengembangan IKM Topeng Malangan. Tahapan analisis strategi menggunakan matriks SWOT berhasil merumuskan tigabelas strategi guna pengembangan IKM Topeng Malangan. Implementasi strategi ini akan menjadi lebih efisien dan efektif maka perlu dilakukan analisis kondisi internal dan eksternal IKM untuk menentukan prioritas strategi yang lebih tepat sasaran. Hasil analisis IFAS dan EFAS menampilkan koordinat pada diagram kartesius SWOT yang merekomendasikan penitikberatan strategi pada upaya pertumbuhan IKM. Rekomendasi ini diperkuat oleh perhitungan nilai strategi kuantitatif yang menitikberatkan prioritas pada strategi SO, artinya pengembangan IKM Topeng Malangan sebaiknya diprioritaskan pada strategi-strategi yang secara maksimal mempergunakan kekuatan organisasi untuk memanfaatkan peluang-peluang yang ada. Dengan dasar ini, dari tiga belas strategi yang dirumuskan pada tahapan analisis SWOT kemudian dispesifikasikan menjadi enam strategi penggunaan kekuatan IKM Topeng
Malangan untuk memanfaatkan peluang yang ada. Kedepannya, akan sangat dibutuhkan penelitian-penelitian lanjutan untuk merumuskan keenam strategi ini dengan lebih rinci dan mengimplementasikannya secara nyata.

\section{DAFTAR PUSTAKA}

David, F.R., 2009. Strategic Management: Concepts and Case, $12^{\text {th }}$ ed, Prentice-Hall.

Departemen Perdagangan Republik Indonesia, 2009. Studi Industri Kreatif Indonesia 2009.

Herdhiansyah, D., Sutiarso, L., Purwadi, D., dan Taryono, 2012. Strategi Pengembangan Potensi Wilayah Agroindustri Perkebunan Unggulan, Jurnal Teknik Industri, 13 (2), 201-209.

Indriasari, L., 2013. Wayang Topeng Malangan, Kisah Klasik Merentang Zaman, Kompas, PT Kompas Media Nusantara.

Johnson, G., Scholes, K., dan Whitington, R., 2011. Exploring Corporate Strategy: Text and Cases, $9^{\text {th }}$ ed, Prentice-Hall.

Melany, 2012. The Strategies Used by Artists in Order to Preserve And Maintain the Existence of Malangan Dance and Mask Art in Malang Municipality, AKEPT $2^{\text {nd }}$ Global Annual Young Researchers Conference and Exhibition.

Rahmana, A., Iriani, Y., dan Oktarina, R., 2012. Strategi Pengembangan Usaha Kecil Menengah Sektor Industri Pengolahan. Jurnal Teknik Industri, 13 (1), 14-21.

Syahza, A., 2003. Pengembangan Usaha Kecil dan Menengah (UKM) untuk Percepatan Peningkatan Ekonomi Daerah di Kabupaten Indragiri Hulu Propinsi Riau. Pusat Pengkajian Koperasi dan Pemberdayaan Ekonomi Masyarakat Universitas Riau Pekanbaru, URL: http://almasdi.unri.ac.id/artikel_pdf/pengemban gan $\% 20$ usaha $\% 20$ kecil\%20dan $\% 20$ menengah $\% 2$ $0(\mathrm{ukm}) \% 20$ untuk\%20percepatan\%20peningkata n\%20ekonomi\%20daerah\%20di\%20kabupaten\%2 0indragiri\%20hulu\%20propinsi\%20riau.pdf. 